\title{
Faktor Risiko Autis Untuk Mengurangi Generasi Autis Anak Indonesia
}

\author{
Autism Risk Factors To Reduce Autistic Generation \\ of Indonesian Children
}

\author{
${ }^{\left({ }^{*}\right)}$ Eka Prasetia Hati Baculu, ${ }^{2)}$ Moh. Andri \\ (1) Department of Nutrition, Public Health Faculty, Muhammadiyah University Palu \\ ${ }^{(2)}$ Department of Public Health Administration, Public Health Faculty, Muhammadiyah University Palu \\ ${ }^{\left({ }^{*}\right)}$ ekaprasetiahati@gmail.com \\ (*) Corresponding Author
}

\begin{abstract}
Abstrak
Autism syndrome dysorder (ASD) atau lebih dikenal dengan autis adalah ganguan perkembangan nerobiologi berat yang terjadi pada anak sehingga menimbulkan masalah pada anak untuk berkomunikasi dan berelasi (berhubungan) dengan lingkungannya. Autis ditandai dengan adanya gangguan dan keterlambatan dalam bidang kognitif, bahasa, perilaku dan interaksi social. Jumlah anak yang terkena autis semakin hari semakin meningkat pesat dan akan semakin menghawatirkan, baik bagi orang tua, masyarakat maupun pemerintah. Penelitian ini bertujuan untuk mengetahui faktor risiko penyebab timbulnya autis pada anak usia 0-14 tahun di Kota Palu. Jenis penelitian case control study. Populasi pada penelitian ini semua anak usia 0-14 tahun yang berada di Kota Palu dan sampel penelitian adalah anak yang melakukan terapi di Rumah Sakit Umum Daerah Madani Kota Palu. Penelitian dimulai pada bulan Januari 2018.Teknik pengambilan sampel dengan total sampling yaitu mengambil semua anak usia 0-14 tahun untuk kasus dan kontrol yang memenuhi kriteria inklusi dan eksklusi. Hasil analisis bivariat menunjukkan asupan makanan $(\mathrm{OR}=35,13 ; 95 \% \mathrm{CI} \quad 4,43-1513,85)$, riwayat kehamilan $(\mathrm{OR}=2,94 ; 95 \% \mathrm{CI} \quad 0,80-7,87)$, riwayat persalinan $(\mathrm{OR}=4,05 ; 95 \%$ CI $1,21-14,15)$, kejang demam $(\mathrm{OR}=3,24 ; 95 \% \mathrm{CI} 0,87-13,47)$, dan pengetahuan ibu $(\mathrm{OR}=4,05 ; 95 \% \mathrm{CI} 1,21-14,2)$ berhubungan signifikan dengan kejadian autis. Kesimpulan: asupan makan, riwayat kehamilan, riwayat persalinan, kejang demam dan pengetahuan ibu merupakan faktor risiko autis pada balita. Saran diharapkan kepada orang tua utamanya ibu untuk lebih memperhatikan asupan makan saat hamil, menyusui dan rutin memeriksakan kehamilannya ke puskesmas serta senantiasa memperhatikan perkembangan anak balitanya sehingga dapat mengetahui dan mencegah sedini mungkin risiko yang dapat menyebabkan autis pada anak.
\end{abstract}

Kata Kunci : Autis, Anak dan Faktor Risiko

\begin{abstract}
Autism syndrome dysorder (ASD) or better known as autism is a disruption of the development of severe nerobiology that occurs in children, causing problems in children to communicate and relate (related) to their environment. Autism is characterized by disturbances and delays in the fields of cognitive, language, behavior and social interactions. The number of children affected by autism is increasing rapidly and will be increasingly alarming, both for parents, the community and the government. This study aims to determine the risk factors for the onset of autism in children aged 0-14 years in Palu City. Case control study type study. The population in this study were all children aged 0-14 years in Palu City and the study sample was children who did therapy at the Madani General Hospital in the City of Palu. The study began in January 2018. The sampling technique with total sampling is taking all children aged 0-14 years for cases and controls that meet the inclusion and exclusion criteria. Bivariate analysis showed food intake $(O R=35.13 ; 95 \%$ CI 4.43-1513.85), pregnancy history $(O R=2.94 ; 95 \%$ CI 0.80-7.87), labor history $(O R=4.05 ; 95 \%$ CI 1.21-14.15), febrile seizures $(O R=3.24 ; 95 \%$ CI 0.87-13.47), and maternal knowledge $(O R=$ 4.05; 95\% CI 1.21-14.2) was significantly associated with autism. Conclusions: food intake, history of pregnancy, history of labor, febrile seizures and knowledge of the mother are risk factors for autism in infants. Suggestions are expected for parents, especially mothers to pay more attention to food intake during pregnancy, breastfeeding and routine pregnancy checks to the health center and always pay attention to the development of their children so that they can know and prevent the risk that can cause autism in children as early as possible.
\end{abstract}

Keywords: Autism, Children and Risk Factors 


\section{PENDAHULUAN}

Pembangunan manusia masa depan dimulai dengan pembinaan anak masa sekarang. Untuk mempersiapkan sumber daya manusia (SDM) yang berkualitas dimasa yang akan datang maka anak perlu dipersiapkan agar anak bisa tumbuh dan berkembang seoptimal mungkin sesuai dengan kemampuannya. Pertumbuhan dan perkembangan anak merupakan hasil interaksi antara faktor genetik-herediter-konstitusi dengan faktor lingkungan, baik lingkungan prenatal maupun lingkungan postnatal. Faktor lingkungan ini yang akan memberikan segala macam kebutuhan dasar yang diperlukan oleh anak untuk tumbuh dan berkembangnya salah satunya adalah kebutuhan akan asupan gizi (1).

Kekurangan gizi berpengaruh negatif terhadap pembangunan mental, perkembangan fisik, produktivitas dan kesanggupan kerja. Kekurangan gizi yang diderita pada masa kandungan dan anak-anak akan menghambat perkembangan kecerdasan. Otak anak yang menderita kekurangan gizi tingkat berat lebih kecil dibandingkan ukuran otak rata-rata, dan mempunyai sel otak yang jumlahnya 15-20\% lebih rendah dibandingkan anak yang berstatus gizi baik. Bahkan anak yang lahir dengan berat lahir rendah (BBLR), karena menderita kurang gizi saat dalam kandungan, akan mengalami kekurangan sel otak hingga 40\% dibandingkan anak normal (2).

Autis adalah suatu gangguan perkembangan pervasif pada anak yang ditandai dengan perkembangan fungsi psikologis yang meliputi gangguan dan keterlambatan dalam bidang kognitif, bahasa, perilaku, komunikasi, dan interaksi sosial. Autis merupakan gangguan perkembangan kompleks yang muncul tiga tahun pertama kehidupan akibat gangguan neurologi yang mempengaruhi fungsi otak dan memerlukan perawatan yang serius oleh tenaga ahli (3). Gangguan ini secara signifikan mempengaruhi komunikasi verbal dan non verbal serta interaksi sosial pada anak (4).

Sampai saat ini penyebab dari autis belum diketahui secara pasti. Ada beberapa faktor yang diduga sebagai penyebab autis. Diantaranya sifat genetik, metabolik dan gangguan syaraf pusat, infeksi pada masa hamil (rubella), gangguan pencernaan hingga keracunan logam berat, struktur otak yang tidak normal seperti hidrosephalus juga dapat menyebabkan anak autis. Selain itu hasil penelitian dari Hannah Gardener (5) menyatakan bahwa faktor perinatal dan neonatal juga merupakan faktor penyebab kejadian autis.

Prevalensi autis beberapa tahun terakhir ini mengalami kenaikan yang signifikan. Center for Diseases Control and Prevention (CDC) di Amerika Serikat pada bulan Maret 2013 melaporkan, bahwa prevalensi autis meningkat menjadi 1:50 dalam kurun waktu setahun terakhir. Hal tersebut bukan hanya terjadi di negara-negara maju seperti Inggris, Australia, Jerman dan Amerika, namun juga terjadi di negara berkembang seperti Indonesia.

Prevalensi autis di dunia saat ini mencapai 15-20 kasus per 10.000 anak atau berkisar 0,15-0,20\%. Jika angka kelahiran di Indonesia 6 juta per tahun maka jumlah penyandang autis di Indonesia bertambah 0,15\% atau 6.900 anak per tahunnya (6). Data dari rumah sakit Madani Kota Palu yaitu selama dua tahun terakhir dari tahun 2015 hingga tahun 2016 jumlah kasus autis pada anak mengalami peningkatan dari jumlah yang kurang dari 9 orang pasien yg terapi naik menjadi lebih dari 20 orang pasien.

Hal ini disebabkan karena masih kurangnya informasi mengenai penyebab dan langkah apa yang harus dilakukan sebagai orang tua untuk menangani kasus anak autis. Sehingga mengakibatkan banyaknya orang tua yang membiarkan kondisi anak mereka dan menggangap lumrah permasalahan ini. Jika hal ini dibiarkan tanpa ada perhatian khusus dan penangganan sejak dini, maka akan berdampak buruk bagi keberlangsungan generasi bangsa kita dimasa yang akan datang. 
Tujuan penelitian ini adalah untuk menganalisis faktor risiko autis pada anak usia 0-14 tahun untuk mengurangi generasi anak autis Indonesia. .

\section{METODE}

Penelitian ini menggunakan metode case control dengan pengambilan sampel adalah semua anak autis yang diterapi di Rumah Sakit Madani Kota Palu dengan matching jenis kelamin.

Kasus adalah anak autis sedangkan kontrol balita normal yang berada pada populasi yang sama. Lokasi penelitian dilaksanakan di Rumah Sakit Madani Kota Palu. Waktu penelitian dimulai pada bulan Mei 2018. Pemilihan lokasi didasarkan karena Rumah Sakit Madani merupakan rumah sakit yang menangani terapi untuk anak berkebutuhan khusus termasuk autis. Sampel yang didapatkan sebanyak 32 anak, karena jumlah sampel yang didapatkan tidak jauh berbeda dari jumlah sampel minimal sehingga diambil total sampling sehingga total sampel 64 untuk kasus dan kontrol dengan perbandingan 1:1 dan matching jenis kelamin.

\section{HASIL}

\section{Analisis Univariat}

Tabel 1

Distribusi Frekuensi Karakteristik Subyek Penelitian

\begin{tabular}{|c|c|c|c|c|c|}
\hline \multirow{2}{*}{ NO } & \multirow{2}{*}{ Variabel } & \multicolumn{2}{|c|}{ Kasus $(n=32)$} & \multicolumn{2}{|c|}{ Kontrol (n=32) } \\
\hline & & $\mathbf{n}$ & $\%$ & $\mathbf{n}$ & $\%$ \\
\hline \multirow[t]{3}{*}{1} & Jenis Kelamin & & & & \\
\hline & Laki-Laki & 26 & 81,25 & 26 & 81,25 \\
\hline & Perempuan & 6 & 18,75 & 6 & 18,75 \\
\hline \multirow[t]{3}{*}{2} & Berat Badan Lahir & & & & \\
\hline & BBLR & 10 & 31,25 & 6 & 18,75 \\
\hline & Normal & 22 & 68,75 & 26 & 81,25 \\
\hline \multirow[t]{3}{*}{3} & Pendidikan Ayah & & & & \\
\hline & Rendah & 7 & 21,88 & 7 & 21,88 \\
\hline & Tinggi & 25 & 78,13 & 25 & 78,13 \\
\hline \multirow[t]{3}{*}{4} & Pendidikan Ibu & & & & \\
\hline & Rendah & 13 & 40,63 & 11 & 34,38 \\
\hline & Tinggi & 19 & 59,38 & 21 & 65,63 \\
\hline \multirow[t]{3}{*}{5} & Asupan Makan & & & & \\
\hline & Konsumsi & 31 & 96,88 & 15 & 46,88 \\
\hline & Tidak Konsumsi & 1 & 3,13 & 17 & 53,13 \\
\hline \multirow[t]{3}{*}{6} & Riwayat Kehamilan & & & & \\
\hline & Kurang $<9$ bulan & 17 & 53,13 & 10 & 31,25 \\
\hline & Cukup $\geq 9$ bulan & 15 & 46,88 & 22 & 68,75 \\
\hline \multirow[t]{3}{*}{7} & Riwayat Persalinan & & & & \\
\hline & Sesar & 17 & 53,13 & 7 & 21,88 \\
\hline & Normal & 15 & 46,88 & 25 & 78,13 \\
\hline \multirow[t]{3}{*}{8} & Kejang Demam & & & & \\
\hline & Kejang Demam & 27 & 84,38 & 20 & 62,50 \\
\hline & Tidak Kejang Demam & 5 & 15,63 & 12 & 37,50 \\
\hline \multirow[t]{3}{*}{9} & Pengetahuan & & & & \\
\hline & Rendah & 25 & 78,13 & 15 & 46,88 \\
\hline & Tinggi & 7 & 21,88 & 17 & 53,13 \\
\hline
\end{tabular}

Ket: $\mathrm{n}=$ jumlah sampel 


\section{Interpretasi}

Berdasarkan hasil analisis deskriptif terlihat sebaran datanya normal. Hal ini terlihat dari asupan makan gluten kasein dan riwayat kejang demam berbeda secara signifikan antara kelompok kasus dan kontrol. Sementara karakteristik subyek lainnya tidak ada perbedaan yang bermakna, hal ini menunjukkan bahwa antara kelompok kasus dan kelompok kontrol memiliki distribusi yang setara dalam karakteristik tersebut.

\section{Analisis Bivariat}

Variabel bebas dengan kejadian autis pada anak

Tabel 2

Analisis Variabel Bebas dengan Kejadian Autis

\begin{tabular}{|c|c|c|c|c|c|c|}
\hline \multirow{2}{*}{ Variabel } & \multicolumn{2}{|c|}{ Kasus $(\mathbf{n}=32)$} & \multicolumn{2}{|c|}{$\begin{array}{c}\text { Kontrol } \\
(n=32)\end{array}$} & \multirow[t]{2}{*}{$P$} & \multirow{2}{*}{$\begin{array}{c}\text { OR } \\
\text { CI } 95 \%\end{array}$} \\
\hline & $\mathbf{n}$ & $\%$ & $\mathbf{n}$ & $\%$ & & \\
\hline \multicolumn{7}{|l|}{ Asupan Makan } \\
\hline Konsumsi & 31 & 96,88 & 15 & 46,88 & $0,000 *$ & 35,13 \\
\hline Tidak Konsumsi & 1 & 3,13 & 17 & 53,13 & & $(4,43-1513,85)$ \\
\hline \multicolumn{7}{|l|}{ Riwayat Kehamilan } \\
\hline Kurang $<9$ bulan & 17 & 53,13 & 10 & 31,25 & 0,07 & 2,49 \\
\hline Cukup $\geq 9$ bulan & 15 & 46,88 & 22 & 68,75 & & $(0,80-7,87)$ \\
\hline \multicolumn{7}{|l|}{ Riwayat Persalinan } \\
\hline Sesar & 17 & 53,13 & 7 & 21,88 & $0,009^{*}$ & 4,05 \\
\hline Normal & 15 & 46,88 & 25 & 78,13 & & $(1,21-14,15)$ \\
\hline \multicolumn{7}{|l|}{ Kejang Demam } \\
\hline Kejang Demam & 27 & 84,38 & 20 & 62,50 & $0,05^{*}$ & 3,24 \\
\hline Tidak Kejang Demam & 5 & 15 & 12 & 37,50 & & $(0,87-13,47)$ \\
\hline \multicolumn{7}{|l|}{ Pengetahuan } \\
\hline Rendah & 25 & 78,13 & 15 & 46,88 & $0,009^{*}$ & 4,05 \\
\hline Tinggi & 7 & 21,88 & 17 & 53,13 & & $(1,21-14,2)$ \\
\hline
\end{tabular}

Keterangan: * = signifikan $(\mathrm{p}<0,05)$

\section{Interpretasi}

Pada uji chi-square, variabel asupan makan gluten dan kasein, riwayat persalinan, kejang demam dan pengetahuan ibu memiliki nilai $p=0,000, p=0,009, p=0,05$ dan $p=0,009$ dimana nilai $p$ lebih kecil dari pada 0,05 , karenya $\mathrm{p}$ lebih kecil dari 0,05 maka hipotesis nol ditolak, artinya terdapat hubungan antara asupan makan gluten dan kasein, riwayat persalinan, kejang demam dan pengetahuan ibu dengan kejadian autis sedangkan variabel riwayat kehamilan emiliki nilai $\mathrm{p}$ value lebih besar dari pada 0,05 amak hipotesis diterima, artinya tidak ada hubungan antara riwayat kehamilan ibu dengan kejadian autis pada anak

\section{PEMBAHASAN}

\section{Asupan Makan Gluten dan Kasein}

Berdasarkan hasil analisis univariat sebagian besar anak autis mengkonsumsi gluten dan kasein 96,88 \% dibandingkan dengan anak tidak terdiagnosis autis. Namun apabila dilihat dari segi Pendidikan orang tua anak autis rata-rata memiliki Pendidikan yang tinggi. Pendidikan yang tinggi memungkinkan orang tua memiliki pengetahuan yang cukup baik dalam hal memilih makanan yang terbaik untuk anaknya.

Hasil analisis bivariat menunjukkan ada hubungan signifikan antara asupan makanan gluten dan kasein dengan kejadian autis pada anak dengan nilai $\mathrm{p}=0,000(\mathrm{p}<0,05)$. Dari hasil analisi OR terlihat nilai OR untuk asupan makan gluten dan kasein sebesar 35, 13 artinya anak yang sering mengkonsumsi gluten n kasein yang berlebih memiliki risiko kejadian ASD (autis sindrom disoreder) sebesar 35, 13 kali lebih besar dibandingkan 
dengan anak yang tidak mengkonsumsi gluten dan kasein yang berlebih dan merupakan faktor risiko.

Gluten merupakan protein yang berasal dari tumbuh-tumbuhan misalnya terigu, oat dan barley sedangkan kasein merupakan protein yang berasal dari susu sapi. Gluten dan kasein tidak diperbolehkan untuk anak autis karena gluten dan kasein termasuk jenis protein yang sulit untuk dicerna didalam tubuh.

Enzim pencernaan pada anak autis sangatlah kurang, sehingga membuat makanan yang mengandung gluten dan kasein tidak dapat dicerna dengan sempurna. Idealnya pada anak normal, protein yang dikonsumsi akan dipecah menjadi asam amino sehingga dapat dipergunakan oleh tubuh melalui mekanisme jalur metabolisme. Namun pada anak autis, karena protein tidak dicerna dengan sempurna, akibatnya akan terjadi rangkaian rantai pendek yang hanya terdiri dari dua asam amino yang disebut peptid (7).

\section{Riwayat Kehamilan Ibu}

Berdasarkan hasil analisis univariat terlihat anak yang lahir lebih cepat bulan atau kurang dari 9 bulan lebih banyak menderita autis sebanyak 53,13\% dibandingkan dengan anak yang normal. Hasil analisis bivariat terlihat tidak ada hubungan yg signifikan antara riwayat kehamilan ibu dengan kejadian autis pada anak, hal ini terlihat karena nilai $p$-value lebih besar dari 0,05 . Namun pada uji OR didapatkan nilai 2,49. Artinya anak yang memiliki riwayat lahir lebih cepat atau prematur memiliki risiko 2,49 lebih besar menderita autis dibandingkan dengan anak yang lahir cukup bulan dan merupakan faktor risiko.

\section{Riwayat Persalinan}

Berdasarkan hasil analisis univariat terlihat anak yang menderita autis rata-rata lahir dengan proses persalinan sesar sebesar 53,17\% dibandingkan dengan anak yang lahir dengan proses normal. Selanjutnya hasil analisis bivariat terlihat ada hubungan signifikan antara riwayat persalinan dengan kejadian autis pada anak. Hal ini terlihat dari nilai $p$-value lebih kecil dari 0,05 yaitu $(\mathrm{p}=0,009)$.

Pada analisis OR terlihat nilai $\mathrm{OR}=4,05$ artinya anak yang lahir sesar atau tidak normal memiliki riwayat menderita autis 4,05 kali lebih besar disbanding dengan anak yang lahir dengan proses persalinan normal dan merupakan faktor risiko.

Selain itu, hasil penelitian juga menunjukkan bahwa anak yang menderita autis sekitar 31,25\% lahir dengan berat badan lahir rendah. Anak yang lahir dengan BBLR dapat diakibatkan karena nutrisi yang kurang baik pada saat masih dalam kandungan. Gangguan nutrisi akan mengakibatkan peredaran darah dari ibu ke janin turun sehingga kebutuhan glukosa maupun oksigen di otak tidak terpengaruhi dengan baik. Akibatnya dapat menyebabkan asfiksia dan iskemia otak, iskemia otak menyebabkan kerusakan sel-sel otak. Bayi yang lahir dengan BBLR dapat mengalami gangguan metabolism yaitu hipoglikemia dan hipoksia, keadaan ini dapat menyebabkan terjadi metabolisme anaerob sehingga otak mengalami kerusakan pada periode perinatal.

\section{Riwayat Kejang Demam}

Kejang demam adalah bangkitan kejang yang terjadi pada kenaikan suhu tubuh (suhu rektal diatas $38^{\circ} \mathrm{C}$ yang disebabkan oleh ekstrakranium. Kejang demam merupakan kelainan neurologis yang paling sering dijumpai pada anak-anak terutama golongan umur 3 bulan sampai 5 tahun.

Berdasarkan hasil analisis univariat terlihat sekitar 84,38\% anak memiliki riwayat kejang demam. Hasil hasil analisis bivariat terlihat ada hubungan yang signifikan antara riwayat kejang demam dengan kejadian autis pada anak dengan nilai $p$ value 0,005. Pada uji OR terlihat nilai OR 3,24 artinya, anak yang memiliki riwayat kejang demam memiliki risiko terkena autis sebesar 3,24 kali lebih besar dibandingkan dengan anak yang tidak memiliki 
riwayat kejang demam diwaktu kecil. Hasil penelitian lain menunjukkan bahwa riwayat keluarga yang pernah menderita kejang demam dapat menjadi salah satu risiko pemicu terjadinya autis pada anak.

\section{Pengetahuan Orang Tua terhadap Tumbuh Kembang}

Berdasarkan hasil analisis univariat didapatkan 78,13 \% anak yang memiliki orang tua dengan pengetahuan rendah terhadap tumbuh kembang anak dibandingkan anak yang normal. Hasil uji bivariat menunjukkan ada hubungan signifikan antara pengetahuan orang tua terhadap tumbuh kembang anak dengan kejadian autis dengan nilai $p$-value lebih kecil dari 0,05 yaitu 0,009 .

Hasil uji OR terlihat pengetahuan orang tua terhadap tumbuh kembang anak dengan kejadian autis menunjukkan nilai OR sebesar 4,05. Artinya anak yang memilki pengetahuan orang tua yang rendah memiliki 4,05 kali lebih besar menderita autis dibandingkan dengan anak yang memiliki orang tua dengan pengetahuan orang tua yang tinggi.

Pendidikan orang tua merupakan salah satu faktor yang penting dalam tumbuh kembang anak, karena dengan pendidikan yang baik orang tua dapat menerima segala informasi dari luar terutama mengenai cara pengasuhan anak yang baik, bagaimana menjaga kesehatan anaknya, pendidikannya dan sebagainya (8). Hasil penelitian Kalsum (9) mengatakan bahwa semakin tinggi tingkat pendidikan kepala keluarga, maka mereka akan berhati-hati untuk memilih fasilitas yang lebih lengkap untuk kesehatan ibu dan anak.

\section{KESIMPULAN}

1. Asupan makanan gluten dan kasein merupakan faktor risiko kejadian autis pada anak di RSUD Madani dengan nilai $\mathrm{OR}=35,13$ artinya anak yang sering mengkonsumsi gluten dan kasein memiliki risiko 35, 13 kali lebih besar menderita autis dibandingkan dengan anak yang tidak mengkonsumsi gluten dan kasein.

2. Riwayat Kehamilan ibu merupakan faktor risiko kejadian autis pada anak di RSUD Madani dengan nilai OR = 2,49 artinya anak yang memiliki riwayat kehamilan ibu lahir kurang dari 9 bulan memiliki risiko 2, 49 kali lebih besar menderita autis dibandingkan dengan anak yang lahir cukup bulan.

3. Riwayat Persalinan merupakan faktor risiko kejadian autis pada anak di RSUD Madani dengan nilai OR $=4,05$ artinya anak yang memiliki riwayat persalinan lahir dengan sesar memiliki risiko 4,05 kali lebih besar menderita autis dibandingkan dengan anak yang lahir secara normal.

4. Riwayat Kejang Demam merupakan faktor risiko kejadian autis pada anak di RSUD Madani dengan nilai OR = 3,24 artinya anak yang memiliki riwayat sering kejang demam memiliki risiko 3,24 kali lebih besar menderita autis dibandingkan dengan anak yang tidak sering terkena kejang demam.

5. Pengetahuan orang tua terhadap tumbuh kembang merupakan faktor risiko kejadian autis pada anak di RSUD Madani dengan nilai $\mathrm{OR}=4,05$ artinya anak yang memiliki orang tua dengan pengetahuan rendah terhadap tumbuh kembang anak memiliki risiko 4,05 kali lebih besar menderita autis dibandingkan dengan anak yang memiliki orang tua dengan pengetahuan yang tinggi.

\section{SARAN}

Diharapkan kepada orang tua utamanya ibu untuk lebih memperhatikan asupan makan saat hamil, menyusui dan rutin memeriksakan kehamilannya ke puskesmas serta senantiasa memperhatikan perkembangan anak balitanya sehingga dapat mengetahui dan mencegah sedini mungkin risiko yang dapat menyebabkan autis pada anak.

\section{DAFTAR PUSTAKA}

1. Narendra B Moersintowarti, Sularyo S Titi, Soetjitiningsih, Suyitno Hariyono, Ranuh Gde N IG, Wiradisuria 
Sambas. 2010. BUKU Ajar I Tumbuh Kembang Anak dan Remaja Edisi Pertama. Pengurus Ikatan Dokter Anak Indonesia. Sagung Seto. Jakarta.

2. Aritonang Irianton. 2012. Perencanaan dan Evaluasi Program Intervensi Gizi Kesehatan. Tantangan Memperoleh Gizi Baik dan Hidup Sehat Pada Era Otonomi Daerah. Lutikabook. Yogyakarta.

3. Alexander Kolevzon, MD; Raz Gross, MD, MPH; Abraham Reichenberg, PhD. 2007. Prenatal and Perinatal Risk Factors For Autism. American Medical Association Arch Pediatr Adolesc Med. 2007;Vol 161:326-333

4. Rusianto Y.C. 2016. Pengaruh Terapi Murottal Surat Al-Mulk Terhadap Respon Kognitif Pada Anak Autis Di Sekolah Luar Biasa Negeri 01 Bantul Yogyakarta, Karya tulis ilmiah, Program Studi Ilmu Ilmu keperawatan Fakultas Kedokteran dan Ilmu Keperawatan Universitas Muhammadiyah Yogyakarta 2016.

5. Hannah Gardener, Donna Spiegelman and Stephen L. Buka. 2011. Prenatal Risk Factors For Autism: Comprehensive Meta-Analysis. Journal of The American Academy of Pediatrics. Pediatrics volume 128, number 2, August 2011.

6. Pratiwi R.A and Dieny, Filla Fithra. 2014.Hubungan Skor Frekuensi diet Bebas Gluten bebas Casein dengan Skor Perilaku Autis. Jurnal eprints.undip.ac.id.

7. Kusumayanti G.A.D. 2011. Pentingnya Pengaturan Makanan Pada Anak Autis, Jurnal Ilmu Gizi, Volume 2 no 1, Februari 2011, hal 1-8.

8. Soetjiningsih. 2014. Tumbuh Kembang Anak edisi 2. EGC. Jakarta.

9. Wardhani A. K. 2013. Kejang Demam Sederhana Pada Anak Usia Satu Tahun. Fakultas Kedokteran Universitas Lampung. Jurnal Medula, Volum 1 Nomor 1, September 2013. 